\title{
LABOR MIGRATION AND HUMAN WELFARE IN UKRAINE UNDER THE CURRENT CONDITIONS: INTERRELATIONSHIP, DEVELOPMENT TRENDS AND WAYS OF TACKLING THE CHALLENGES
}

\author{
${ }^{a}$ Ukrainian State University of Chemical Technology, Dnipro, Ukraine

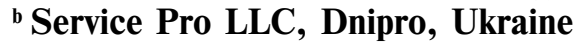

\begin{abstract}
The globalization component of the modern economy is characterized by an increase in the intensity of labor migration, especially indicators of its activation within the framework of integration associations, in particular, the countries of the European Union. Labor migration has positive and negative consequences for both donor countries and recipient ones. The European development vector chosen by Ukraine allowed the signing of a number of agreements with the countries of the European Union, giving an opportunity to increase the mobility of its citizens, including labor. On the one hand, it allowed the population of Ukraine to improve the well-being of their families through money transfers from labor migrants from abroad, to reduce the unemployment rate in the country, to get an education in leading universities in Europe, to increase their own human capital by participating in work with advanced technologies etc. On the other hand, it gave rise to a number of social and economic consequences, namely: the outflow of skilled labor, mainly to the European labor market, the shortage of labor for certain professions, the fall in gross national product, non-payment of taxes to the budget and contributions to the pension fund and social insurance funds, the emergence of the so-called social orphanhood, etc. The main reason for the negative balance of labor migration, first of all, is the difference in the level of economic development of countries, political and economic crises in Ukraine, aggression from the Russian Federation, Crimean annexation and the antiterrorist operation in Donbas. This necessitates the development and implementation of a balanced state migration policy in order to return migrant workers to the country, including measures aimed at improving the social and economic situation, resolving military conflict, improving the quality of education, increasing the welfare of the population, etc.
\end{abstract}

Keywords: migration, emigration, immigration, integration, welfare, living standards, human development index, unemployment, income, salaries and wages, migration policy, social policy.

DOI: $10.32434 / 2415-3974-2019-9-1-49-54$

\section{Introduction and issue statement}

Global economy on its current stage of development is characterized by deepening of integration processes in conditions of globalization. This influences on formation and directions for the development of social and labor relations. Nowadays one of the mainstreaming aspects of the abovementioned observations is external migration on a large scale, that is particular evident on labor market. Its significant occurrence is observed in such integration associations as European Union, where favorable conditions for the highest mobility and rapid adaptation on European labor market are provided.
The primary reason of labor migration is a wealth disparity between different countries. Ukraine considered the European path of development and signed numerous agreements contributing to further integration into European community that is caused to population mobility acceleration especially on labor market. Besides the range of positive consequences, the challenge comes up to Ukraine that is outflow of qualified labor force to neighboring countries with higher economic development (Poland, the Check Republic, and Slovakia etc.). The main reason of this is a dramatic deterioration of economic situation in Ukraine, drop in the

(C) Ruban O.V., Dryuk O.G., 2019 
standards of living, armed conflict in the East of Ukraine, annexation of Crimea and emergence of so-called internally displaced people etc. Negative conditions existing on inner labor market as well as lack of qualified staff requires elaboration and justification of proper migration policy from the State, aimed at return of workers and strengthening motivation of employees to enhance their productive skills, efficient use of human capital in order to improve Ukrainian economy competitiveness. This explained the relevance of article subject.

\section{Analysis and research of publications}

Relations between migration processes and the welfare of the population in Ukraine, the main directions and levers of migration policy was studied in the works of foreign economists E. Ravenstein, R. Erenburg, R.S. Smith, P. Krugman, B.M. Genkin, N.A. Gorlov, and in the works of Ukrainian scientists E. M. Libanova, N.I. Yesinova, T. Zaslavskaya, O.V. Poznyak, Z.V. Gbur, O.A. Malinovsky, K. Nikolaets, O.A. Proboyiva, I.M. Biletska and others. However, despite numerous scientific developments in this field, some aspects of the relationship between labor migration and the welfare of the population in Ukraine at the present stages of its development trends are not disclosed and require a more detailed study.

\section{The purpose of the article}

The purpose of this article is to study the interconnection, dynamics and main trends of the development of migration processes and welfare of the population in Ukraine, substantiation of ways to overcome the negative tendencies and directions of improvement of the state migration and social policy in order to achieve its sustainable economic growth.

\section{Statement of the main research material}

The globalization processes, inherent in the modern international economy, lead to an increase in the intensity of global migration flows. According to UN studies, the number of international migrants in 2017 increased by $20 \%$ compared to 2010, amounting to 258 million people, which is almost $3.3 \%$ of the world's population [1, P.5]. Out of them 164 million are migrant workers, which is about $4.7 \%$ of the world's workforce [1, P.5].

Typically, donor countries of migration flows are countries where the level of economic development is lower than the recipient country. From the point of view of some scientists, there are both positive and negative consequences of the impact of labor migration on the economic development of donor countries and recipient ones [2], [3], [4].

Recipient countries have the opportunity to use cheaper qualified foreign labor in the labor-intensive and unattractive sectors of the economy, ensuring their normal functioning, increase the demand for national producers' products, and help to stabilize the personnel shortage in regions with a difficult demographic situation (low birth rates, aging of the population etc.) as well as to reduce expenditures for training of hired labor. However, an increase in migration flows leads to the outflow of national currency abroad, social tensions and unrest in the country, growth of crime rates, and the surge of public spending on social security and legal protection of immigrants, a negative attitude towards them.

In our opinion, the increase in foreign labor migration in Ukraine in recent years is a real threat to the development of the national labor market and the economy of the country as a whole. According to the World Bank report, Ukraine is among the top ten donors [5]. According to some experts, the number of migrant workers who work abroad is between 3 and 9 million people [6], and migration is mainly commuting (i.e. the average period of their stay abroad is 3 months).

However, official statistic that would precisely

\section{Advantages and disadvantages of labor migration}

\begin{tabular}{l|l}
\hline \multicolumn{1}{c|}{ Positive impact } & \multicolumn{1}{c}{ Negative consequences } \\
\hline Inflow of cash transfers & Loss of GDP share \\
\hline Redistribution of labor force & Non-payment of taxes \\
\hline Population welfare improvement & Non-payment of contributions to the pension funds \\
\hline Attraction of investments (creation of start-up capital) & Deterioration of demographic indicators \\
\hline Opportunity to apply cutting-edge technology & Disruption of families (social orphan hood) \\
\hline Human capital growth & Outflow of qualified workforce \\
\hline Reduction of unemployment rate & Social insecurity \\
\hline Familiarity with the culture of other countries & Lack of personnel in the labor market \\
\hline & Discrimination \\
\hline & Forced labour \\
\hline & Sexual violence \\
\hline & Human trafficking \\
\hline & Illegal migration \\
\hline &
\end{tabular}


determine the number of those who work abroad does not reflect the real state of affairs, since most of immigrants are illegal [7, p.56]. Ukrainian migrants are mainly young productive masculine population the age of 15-40 years old (except Italy where women dominate among Ukrainian workers), who mostly have technical and vocational or secondary education and are employed in construction, engaged in keeping up the houseworks, agriculture, wholesale and retail trade, and so on.

What are the main reasons for the economically active population of Ukraine to seek a better fate abroad and what consequences can it lead to?

In our opinion, the upsurge in the intensity of labor migration in Ukraine is due to the existence of an economic and political crisis in the country in view of events related to the aggression of the Russian Federation (the annexation of the Crimea and an antiterrorist operation on the territory of the Donbas). This leads to an increase in the internal migration, including labor one. The signing of the Association with the European Union and the establishment or simplification of the visa-free regime in some countries played a significant role in the intensification of this process.

One of the crucial determinants of labor migration abroad is the difference in salaries in Ukraine and recipient countries. The main directions of our emigrants are Poland, Russia, Slovenia, the Czech Republic etc., part of the economically active population of which is working in more economically developed countries of the European Union and the world, for example, in Germany and in Scandinavia, so they are forced to stimulate the inflow of skilled foreign labor, closer to their mentality. According to Eurostat, the average monthly salary in the most popular among migrants countries in the European Union is following: in Bulgaria - 637.29 euros, Czech Republic -1249.64 euros, Poland -1114.75 euros, Slovenia - 2018.49 euros, Slovakia - 1258.82 euros. In Turkey, where there is a priority to create comfortable environment for young people to enter the tourism business in the summer, the average salary per month is 1245.00 euros [10], while in Ukraine it is 264 euros [11], which indicates a contradiction between the amount of wages in the country and the cost of living in it. Therefore, this is a significant reason of intensive labor migration of Ukrainians abroad, even though in most countries social protection of foreign labor force (conditions and labor protection, working time, medical care, accommodation guarantees, pension, etc.) is almost absent.

According to the World Bank, Ukraine is among the TOP-10 donor countries in the world, whose labor migrants have transferred the largest funds in 2018 counting up to $\$ 14.4$ million. [5,
Table 2

Dynamics of remittances to Ukraine from abroad by migrant workers in 2008-2018 (in millions of US dollars) [9]

\begin{tabular}{c|c|c|c}
\hline Year & $\begin{array}{c}\text { Received funds } \\
\text { (in millions of } \\
\text { US dollars) }\end{array}$ & $\begin{array}{c}\text { Absolute deviation } \\
\text { year-to-year } \\
\text { (in millions of US } \\
\text { dollars) }\end{array}$ & $\begin{array}{c}\text { Relative } \\
\text { deviation } \\
(\%)\end{array}$ \\
\hline 2008 & 6177 & & $-13,1$ \\
\hline 2009 & 5370 & $-807,0$ & $+9,2$ \\
\hline 2010 & 5862 & $+492,0$ & $+19,7$ \\
\hline 2011 & 7019 & $+1157,0$ & $+7,2$ \\
\hline 2012 & 7526 & $+507,0$ & $+13,4$ \\
\hline 2013 & 8537 & $+1011,0$ & $-24,0$ \\
\hline 2014 & 6489 & $-2048,0$ & $+7,2$ \\
\hline 2015 & 6959 & $+470,0$ & $+8,3$ \\
\hline 2016 & 7535 & $+576,0$ & $+23,3$ \\
\hline 2017 & 9287 & $+1756,0$ & $+17,2$ \\
\hline 2018 & 1088 & $+1601,0$ & \\
\hline
\end{tabular}

p.2], although the National Bank of Ukraine estimates this amount to be approximately $\$ 11$ million. [8].

The dynamics of money transfers to Ukraine from abroad in 2008-2018 is shown in Table. 2

Money transfers from labor migration to households make it possible to increase the welfare of certain categories of population and the national economy, in particular, its components, such as standards of living, to stimulate aggregate demand, stabilize the national currency rate, etc.

The dynamics of money transfers to Ukraine from abroad in 2008-2018 in the relative measurement is highlighted in Figure.

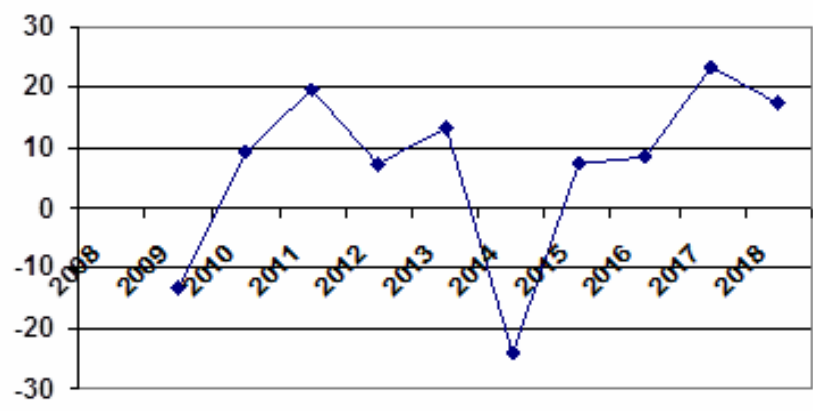

Dynamics of remittances to Ukraine from abroad in 2008-2018 in relative measurement (based on data from Table 2)

The given statistics reveal to the trend of a gradual decrease of money transfers to Ukraine from abroad, which, in our opinion, demonstrates the intentions of saving money of labor migrants in order to obtain a permanent residence in the recipient country.

This problem is compounded by the fact that labor migration has a strong link with educational 
migration. Firstly, the vector of migration flows has recently changed: entrants began to connect a trip to study abroad with the possibility of reuniting with their families. Secondly, domestic highly qualified human capital cannot be implemented on the national labor market [12]. Thirdly, overseas universities of the most attractive recipient countries for Ukrainians offer the possibility of obtaining higher education without the need to pass an independent external testing, only on the average score of the certificate. In addition, there are chances of getting a place for government orders, a state grant, a scholarship program, a double diploma, internship abroad, etc.

According to the CEDOS think-tank, now about $60 \%$ of Ukrainians study abroad, which is almost 3,5\% of Ukrainian students [12]. Most of them, who is skilled labor, remain employed in the country where they were educated, or migrate to work or to continue their education in order to obtain a second educational master level in the countries of the European Union.

Firstly, this is the emergence of an imbalance between the supply and demand for employees in the labor market of Ukraine, as evidenced by the negative index of natural population growth in the country. Ukrainian population is reduced every year by about 100 thousand persons, and now, according to the State Statistics Committee of Ukraine, it is 41.91 million people. [11].

Secondly, the outflow of an economically active part of the labor force abroad on the one side allows mitigate the negative tendencies in the labor market. But on the other hand this is the reason for the shortage on it. As the result is the presence of syndrome of the so-called «human hunger» among some professions, in particular, miscreants, builders, bricklayers, painters, locksmiths, carpenters, plumbers, installers, production workers, seamstresses, etc., which, in turn, leads to slight increase in wages in this fields.

Thirdly, the presence of labor migration has such disadvantages as the emergence of a number of social and economic phenomena called «social orphan hood», GDP expenditure growth because of underutilization of economically active population as a GDP component, nonpayment of taxes to the state budget, pension fund deficit due to nonpayment of contributions to it, etc.

Thus, it is possible to make conclusions about the economic security risk because of intensification of labor migration processes in Ukraine and the necessity to ensure sustainable economic development of the country. For this, we consider it is necessary to improve and implement a balanced migration policy by the state in order to return labor migrants to the national market.
In our opinion, the state should take the following measures for developing a program that will stabilize the migration situation in Ukraine, the outflow of skilled working age labor from the country, improvement of the demographic situation:

- to improve the collection of data concerning the number of migrant workers in Ukraine;

- to facilitate the signing of bilateral agreements on the rights of migrant workers regarding social protection and equality of rights between citizens of Ukraine and citizens of countries, both donors and recipients;

- to develop and improve a united data base with the information about the situation in the labor market in Ukraine and its practical implementation into the system of vocational training and retraining;

- to adopt the changes to the Tax Code for enterprises that create additional jobs and provide privileged places by the state for them;

- to facilitate the attraction of foreign investments to the agrarian and industrial sector of Ukraine in order to achieve its sustainable economic development;

- to improve the quality of education, to monitor the labor market in order to overcome the disparities between demand and supply on the domestic labor market;

- to provide measures of the state migration policy in combination with demographic and social policies, etc.

\section{Conclusions}

On the one hand international labor migration contributes to increasing the competitiveness of national producers; on the other hand, there is a significant issue for the functioning of the world labor market because of the dispersion growth at the economic level of development of countries. According to the authors, the solution of this problem is the prerogative of the State Employment Services, the Border Guard and the International Employment Service, etc. Therefore, we propose to develop and consider a set of measures that could address the problems of income differences in general and gender equality in particular.

\section{REFERENCES}

1. United Nations, Department of Economic and Social Affairs, Population Division (2017). International Migration Report 2017: Highlights (ST/ESA/SER.A/404).

2. Matrosova L.V. Osoblyvosti I stan trudovoyi migraziyi v Ukrayini ta // Ekonomichny visnyk Donbasu. - 2008. - № 4(14). - P.15-22.

3. Esinova N.I., Karaush A.I., Nikitina E.V. Osoblyvosti mizhnarodnoyi trudovoyi migrsziyi v Ukrayini // Ekonomichna strategiya i perspektyvyrozvytku sfery torgivli ta poslug, -2016. 
- Vol.1. - P.124-131.

4. Blyznyuk V. Sozialno-ekonomichni skladovi trudovoyi migraziyi // Visnyk KNTEU. - 2014. - № 4. - P.20-32.

5. Migration and Remittances: Recent Developments and Outlook, Team Social Protection and Jobs World Bank, April 2019.

6. Zentr ekonomichnoyi strategiyi. Skilki ukrayinziv poyihalo za kordon I chto z zym robyty: Analitychna zapyska. Electronic resours. Retried from: https://ces.org.ua/wp-content/ uploads/2018/04/Migration-note.pdf. (accessed 2017).

7. Proboyiv O.A., Biletska I.M. Ukrayina v konteksti globalnyh ekonomichnyh prozessiv // Ekonomika ta suspilstvo. - 2017. - Vol.10. - P.54-60.

8. Ofizsiyny sait Nazionalinogo Banku Ukrayiny. Electronic resours. Retried from: www.bank.gov.ua (accessed 2019).

9. Ofizsiyny sait Ministerstva finansiv Ukrayiny. - Electronic resours. Retried from: https://index.minfin.com.ua/ua/economy/ transfer/ (accessed 2019).

10. Ofizsiyny sait Evrostata. - Electronic resours. Retried from: https://ec.europa.eu/eurostat/web/main/home (accessed 2019).

11. Ofizsiyny sait Derzhavnoyi sluzhby statystyky. Electronic resours. Retried from: www.ukrstat.gov.ua (accessed 2019).

12. Analitychna dopovid do Sshorichnogo Poslannya Prezydenta Ukrayiny do Verhovnoyi Rady Ukrayiny "Pro vnutrishnye ta zovnishnye stanovyzche Ukrayiny v 2018 rozi» Kiyiv: NICD, 2018. -688 p.

Received 12.04.2019

Reviewer: Doct. of Econ. Sc., Ass. Prof. Fedulova S.O.

\section{МІГРАЦІЯ ТА ДОБРОБУТ НАСЕЛЕННЯ УКРАЇНИ В СУЧАСНИХ УМОВАХ: ВЗАЕМОЗВ'ЯЗОК, ТЕНДЕНЩЇ РОЗВИТКУ ТА ШЛЯХИ ПОДОЛАННЯ}

\section{Рубан О.В., Дрюк О.Г.}

Для глобалізаційної складової сучасної економіки $є$ характерною підвищення інтенсивності трудової міграції, особливо щодо показників їі активізації в межсах інтеграційних угрупувань, зокрема країн Свропейського Союзу. Трудова міграція має як позитивні, так і негативні наслідки, як для країндонорів, так і для країн-реципієнтів. Європейський вектор розвитку, який обрала Україна, обумовив підписання низки угод з країнами Свропейського Союзу, що надало можливість підвищити мобільність їі громадян, в тому числі і трудову. 3 одного боку, ие дозволило населенню України підвищити добробут своїх родин за рахунок грошових переказів від трудових мігрантів зза кордону, знизити рівень безробіття в країні, отримати освіту в провідних вишах Європи, підвищити власний людський капітал за рахунок залучення до передових технологій тощо. 3 іншого, - це призвело до низки соціально-економічних наслідків, зокрема, відтоку кваліфікованої робочої сили, насамперед, до європейського ринку праці, дефіциту робочої сили на деякі професії, падінню валового національного продукту, несплати податків до бюджету та відрахувань у пенсійний фонд і фонди соціального страхування, появи так званого соціального сирітства тощо. Головною причиною негативного сальдо трудової міграції, насамперед, є різниця в рівні економічного розвитку країн, наявність політичної та економічної кризи в Україні, агресія з боку Російської Федерації, анексія Криму та проведення антитерористичної операції на Донбасі. Це обумовлює необхідність розробки та впровадження зваженої державної міграційної політики з метою повернення трудових мігрантів в країну, в тому числі заходи, спрямовані на поліпшення соціально-економічної ситуації, розв 'язання воєнного конфлікту, підвищення якості освіти, зростання добробуту населення тощо.

Ключові слова: міграція, еміграція, імміграція, інтеграція, добробут, життєвий рівень, індекс людського розвитку, безробіття, доходи, заробітна плата, міграційна політика, соціальна політика.

\section{МИГРАЦИЯ И БЛАГОСОСТОЯНИЕ ОБЩЕСТВА В УКРАИНЕ В СОВРЕМЕННЫХ УСЛОВИЯХ: ВЗАИМОЗАВИСИМОСТЬ, ТЕНДЕНЦИИ РАЗВИТИЯ И ПУТИ ПРЕОДОЛЕНИЯ}

\section{Рубан О.В., Дрюк О.Г.}

Для глобализационной составляющей современной экономики характерным являются повышение интенсивности трудовой миграции, особенно показателей ее активизации в рамках интеграционных оббеднений, в частности стран Европейского Союза. Трудовая миграция имеет положительные и отрицательные последствия как для стран-доноров, так и для стран-реципиентов. Европейский вектор развития, выбранный Украиной, позволил подписать ряд соглашений со странами Европейского Союза, дающих возможность повысить мобильность ее граждан, в том числе трудовую. С одной стороны, это позволило населению Украины повысить благосостояние своих семей за счет переводов денежных средств от трудовых мигрантов из-за границы, знизить уровень безработицы в стране, получить образование в ведущих вузах Европы, повысить собственный человеческий капитал за счет участия в работе с передовыми технологиями и т.д. С другой стороны, это породило ряд социально-экономических последствий, а именно: отток квалифицированной рабочей силы, главным образом, на европейский рынок труда, дефицит рабочей силы на определенные профессии, падение валового национального продукта, неуплату налогов в бюджет и отчислений в пенсионный фонд и фонды социального страхования, возникновения так называемого социального сиротства и т.д. Основной причиной наличия отрицательного сальдо трудовой миграции, прежде всего, является разница в уровне економического развития стран, политический и экономический кризисы в Украине, агрессия со стороны Российской Федерации, анексия Крыма и проведение антитеррористической операции на Донбассе. Это обуславливает необходимость разработки и внедрения сбалансированной государственной миграционной политики с целью возвращения трудовых мигрантов в страну, в том числе меры, направленные на улучшение социально-экономической ситуации, разрешения военного конфликта, повышение качества образования, рост благосостояния населения и т.д.

Ключевые слова: миграция, эмиграция, иммиграция, интеграция, благосостояние, жизненный уровень, индекс человеческого развития, безработица, доходы, заработная плата, миграционная политика, социальная политика. 


\section{LABOR MIGRATION AND HUMAN WELFARE IN UKRAINE UNDER THE CURRENT CONDITIONS INTERRELATIONSHIP, DEVELOPMENT TRENDS AND WAYS OF TACKLING THE CHALLENGES}

Ruban O.V. ${ }^{a, *}$, Dryuk O.G. ${ }^{b}$

a Ukrainian State University of Chemical Technology, Dnipro, Ukraine

b Service Pro LLC, Dnipro, Ukraine

* e-mail: ovr1975@gmail.com

The globalization component of the modern economy is characterized by an increase in the intensity of labor migration, especially indicators of its activation within the framework of integration associations, in particular, the countries of the European Union. Labor migration has positive and negative consequences for both donor countries and recipient ones. The European development vector chosen by Ukraine allowed the signing of a number of agreements with the countries of the European Union, giving an opportunity to increase the mobility of its citizens, including labor. On the one hand, it allowed the population of Ukraine to improve the well-being of their families through money transfers from labor migrants from abroad, to reduce the unemployment rate in the country, to get an education in leading universities in Europe, to increase their own human capital by participating in work with advanced technologies etc. On the other hand, it gave rise to a number of social and economic consequences, namely: the outflow of skilled labor, mainly to the European labor market, the shortage of labor for certain professions, the fall in gross national product, non-payment of taxes to the budget and contributions to the pension fund and social insurance funds, the emergence of the so-called social orphanhood, etc. The main reason for the negative balance of labor migration, first of all, is the difference in the level of economic development of countries, political and economic crises in Ukraine, aggression from the Russian Federation, Crimean annexation and the antiterrorist operation in Donbas. This necessitates the development and implementation of a balanced state migration policy in order to return migrant workers to the country, including measures aimed at improving the social and economic situation, resolving military conflict, improving the quality of education, increasing the welfare of the population, etc.

Keywords: migration, emigration, immigration, integration, welfare, living standards, human development index, unemployment, income, salaries and wages, migration policy, social policy.

\section{REFERENCES}

1. United Nations, Department of Economic and Social Affairs, Population Division (2017). International Migration Report 2017: Highlights (ST/ESA/SER.A/404) [in English].

2. Matrosova, L.V. (2008) Osoblyvosti I stan trudovoyi migraziyi v Ukrayini ta Donbassi [Features and the state of labor migration in Ukraine and Donbass]. Ekonomichny visnyk Donbasu, № 4(14), 15-22 [in Ukrainian].

3. Esinova, N.I., Karaush, A.I., Nikitina, E.V. (2016) Osoblyvosti mizhnarodnoyi trudovoyi migrsziyi v Ukrayini [Features the labour migration in Ukrain in modern conditions]. Ekonomichna strategiya i perspektyvyrozvytku sfery torgivli ta poslug, Vol. 1, 124-131 [in Ukrainian].

4. Blyznyuk, V. (2014) Sozialno-ekonomichni skladovi trudovoyi migraziyi [Socio-economic components of labor migration]. Visnyk KNTEU, № 4, 20-32 [in Ukrainian].

5. Migration and Remittances: Recent Developments and Outlook, Team Social Protection and Jobs World Bank, April 2019. [in English].

6. Zentr ekonomichnoyi strategiyi (2017) Skilki ukrayinziv poyihalo za kordon I chto z zym robyty: Analitychna zapyska [Several Ukrainians went abroad and what to do with it]. - Electronic resours. Retried from: https://ces.org.ua/wp-content/uploads/2018/04/Migration-note.pdf. (accessed 2017).

7. Proboyiv, O.A., Biletska, I.M. (2017) Ukrayina v konteksti globalnyh ekonomichnyh prozessiv [Ukrein in the context of global migration processes]. Ekonomika ta suspilstvo, Vol. 10, 54-60 [in Ukrainian].

8. Ofizsiyny sait Nazionalinogo Banku Ukrayiny (2019). [Official site of the National Bank of Ukraine]. Electronic resours. Retried from: www.bank.gov.ua (accessed 2019).

9. Ofizsiyny sait Ministerstva finansiv Ukrayiny (2019). [Official site of the Ministry of Finance of Ukraine]. Electronic resours. Retried from: https://index.minfin.com.ua/ua/economy/ transfer/ (accessed 2019).

10. Ofizsiyny sait Evrostata (2019) [Official site of Eurostat]. Electronic resours. Retried from: https://ec.europa.eu/eurostat/web/main/home (accessed 2019).

11. Ofizsiyny sait Derzhavnoyi sluzhby statystyky (2019). [Official site of the State Statistics Service]. Electronic resours. Retried from: www.ukrstat.gov.ua (accessed 2019).

12. Analitychna dopovid do Sshorichnogo Poslannya Prezydenta Ukrayiny do Verhovnoyi Rady Ukrayiny «Pro vnutrishnye ta zovnishnye stanovyzche Ukrayiny v 2018 rozi» [An Analytical Report to the Annual Address of the President of Ukraine to the Verkhovna Rada «On the Internal and External Situation of Ukraine in 2018»] - Kiyiv : NICD, 688 [in Ukrainian]. 